\title{
The Effect of Chocolate Consumption on The Level of Anxiety in Primigravida Third Trimester Pregnant Women At Jatikalen Health Center Nganjuk District
}

\author{
Meirna Eka Fitriasnani*, Anis Nikmatul Nikmah \\ Department of Midwifery Science, Kadiri University, Kediri, Indonesia \\ * meirna.eka@unik-kediri.ac.id
}

\begin{abstract}
Pregnancy is a natural and physiological process but can be a source of stressor anxiety, especially in primigravida pregnant women. At the time before delivery, pregnant women often experience stress, fear, and anxiety. The level of anxiety of pregnant women increases during childbirth. Various non-pharmacological efforts were made to reduce the anxiety of pregnant women in facing childbirth. One of them is by consuming chocolate because chocolate contains Phenylethylamine compounds which can increase serotonin in the brain which provides a comfortable and relaxing effect. Besides, chocolate is also able to reduce levels of the hormone cortisol and catecholamines, which are hormones that trigger anxiety. The purpose of this study was to determine the effect of chocolate consumption on anxiety levels in third-trimester primigravida pregnant women. This research is a pre-experimental study with one group pre-test post-test design. The population was pregnant women aged $\geq 32$ weeks primigravida, the sampling technique used was a total population of 16 respondents. The data collected were analyzed using the Wilcoxon test.
\end{abstract}

Keywords : Anxiety, Primigravida Pregnant Women, Chocolate Consumption 


\section{STRADA Jurnal Ilmiah Kesehatan}

DOI: $10.30994 /$ sjik.v9i2.428

ISSN: 2252-3847 (print); 2614-350X (online)

Vol.9 No.2 November 2020 Page.1056-1064

\section{BACKGROUND}

Pregnancy is one of the most important and stressful events in a woman's life (George et al. 2013). Pregnancy is the growth and development of an intrauterine fetus from conception and ending until the onset of labor. Pregnancy is an emotional crisis (Ding et al. 2014) which if not managed properly will become a prolonged crisis that can impact both mother and baby (Glover 2014). During pregnancy, the mother experiences physiological and psychological changes wherein the process of adjusting to this new state often causes anxiety(Fauzia Laili 2017)(Winda Martalisa 2013). Pregnant women experience stress, fear, and anxiety where this anxiety will increase before delivery (Ding et al. 2014). Anxiety is a feeling of anxiety as if something bad is going to happen and feeling uncomfortable as if there is a threat. A mother may feel fear of the pain and physical danger that will arise during childbirth (Glover 2014). Fear before childbirth is often experienced by mothers during pregnancy. This anxiety can be experienced by both primiparous and multiparous mothers. For primigravida mothers (first-time pregnant women) pregnancy is the first experience in their life period. This situation can cause drastic changes both in the mother's physical and psychological (Cicek and Basar 2017). Primigravida pregnant women usually experience a lot of worries, fear mixed with anxiety about pregnancy and childbirth. As the pregnancy gets older, the attention and thoughts of pregnant women begin to focus on something that is considered a climax, so that the anxiety and fear experienced by pregnant women will intensify just before childbirth (Winda Martalisa 2013).

Anxiety in pregnancy is one of the factors that can hurt the birth of a baby (Schetter and Tanner 2012). Various studies have shown that stress or anxiety during pregnancy affects the mental health of the mother and fetal growth and can lead to preterm birth (Shapiro and Fraser 2016). For most women, pregnancy is a time that is prone to mental disorders. A large number of women experience anxiety disorders or mood swings during pregnancy or in the first few months after childbirth. For women who have a history of psychiatric disorders at a higher risk of experiencing anxiety disorders during pregnancy. Psychological stress during pregnancy negatively impacts the well-being of the mother and the fetus (Bunevičius et al. 2015)(Goodman et al. 2010). Primigravida pregnant women are particularly prone to experience stress and anxiety as they transition to new mothers and enter their role as new mothers in their lives. A study of primigravida pregnant women showing that primigravida pregnant women initiating the transition to motherhood early in their pregnancy reported that they felt they had lost control of their lives (Darvill, Skirton, and Midwife 2010). A qualitative study shows that primigravida pregnant women experience significant shifts and transformations in terms of self-identity, social relations, and work (Bann et al. 2016). Primigravida pregnant women have no previous pregnancy experience. The stress and anxiety levels in primigravida pregnant women are higher than in multigravida pregnant women (Dipietro and Sipsma 2008). The prevalence of anxiety disorders during pregnancy, in developed and developing countries is $10 \%$ and $25 \%$, respectively (Bann et al. 2016)(Ding et al. 2014) (Glover 2014). The incidence of anxiety in pregnant women in Indonesia reaches 107,000 people $(28.7 \%)$. It can be concluded that there are still many pregnant women who experience anxiety before childbirth. Anxiety will increase the hormones adrenaline and noradrenaline or epinephrine and norepinephrine, causing dysregulation of the body's biochemistry, resulting in physical tension in pregnant women.Salah satu upaya non farmakologis dalam mengurangi kecemasan adalah dengan mengkonsumsi cokelat. Cokelat mengandung phenethylamine yang memicu pelepasan endorphin yang mampu meningkatkan kebahagiaan. Cokelat 


\section{STRADA Jurnal Ilmiah Kesehatan}

DOI: $10.30994 /$ sjik.v9i2.428

ISSN: 2252-3847 (print); 2614-350X (online)

Vol.9 No.2 November 2020 Page.1056-1064

mengandung serotonin, anti-depresan alami. cokelat juga mampu menjadi neutransmiter guna mengurangi depresi/kecemasan (Kristanto Aji 2012).

Research conducted by researchers at the Nestle Research Center in Lausanne, Switzerland, published in the Journal of Proteome Research shows that consuming this type of chocolate every day for two weeks can reduce levels of the stress hormone cortisol and catecholamines in those with high anxiety levels. Researchers looked at the effects of consuming 40 grams of dark chocolate daily for two weeks with urine and blood measurements in 30 healthy adults. Participants' anxiety levels were determined at the start of the study, and samples for both blood and urine were collected and analyzed at the start and end of the two-week study. The result is that daily consumption of dark chocolate will reduce stress hormone levels in those with high anxiety levels (Jayantika 2012).

\section{METHOD}

This research is a pre-experimental study with the One Group Pre Test Post Test Design approach where the researcher can test whether any changes have occurred after the treatment. This researcher was conducted by giving a pre-test before being given treatment, after being given treatment, then giving a post-test. The study was conducted by assessing the anxiety level of primigravida pregnant women before being treated with the powdered chocolate (dark chocolate) compound in the HARS scale for 120 minutes and the post-test was carried out after giving powdered chocolate (dark chocolate) compound diluted with warm water $370 \mathrm{C}$ as much as $150 \mathrm{cc}$, was given once a day for 2 weeks and gave a questionnaire on the HARS scale containing the anxiety scale measures. Cocoa powder was given to respondents in powder packaging with instructions on how to serve it. This research was conducted in the Jatikalen Public Health Center, Nganjuk Districtin July-August 2020. The independent variable in this study was the provision of chocolate consumption and the dependent variable in this study was pregnant women's anxiety. primigravida. The population in this study was $\geq 32$ weeks primigravida. This study uses a total population technique. The sample in this study were all primigravida pregnant women aged $\geq 32$ weeks. The instruments used were observation sheets and an anxiety questionnaire (HARS scale). The analysis in this study used the Wilcoxon statistical test.

\section{RESULTS}

\section{General Data}

\section{1) Distribution of Respondents by Age}

Tabel 1 Frequency Distribution of Respondent Characteristics by Age at Jatikalen Public Health Center Nganjuk District

\begin{tabular}{ccc}
\hline Umur & Frequency & Prosentase \\
\hline$<20$ year & 3 & 18,75 \\
20-35 year & 13 & 81,25 \\
$>35$ year & 0 & 0 \\
\hline Total & 16 & 100 \\
\hline
\end{tabular}

Based on table 1 above, it can be interpreted that almost all of the respondents $(81,25 \%)$ are aged $20-35$ years. 


\section{STRADA Jurnal Ilmiah Kesehatan}

DOI: $10.30994 /$ sjik.v9i2.428

ISSN: 2252-3847 (print); 2614-350X (online)

Vol.9 No.2 November 2020 Page.1056-1064

2) Distribution of Respondents by Education

Tabel 2 Frequency Distribution of Respondent Characteristics by Education at Jatikalen Public Health Center Nganjuk District

\begin{tabular}{lcc}
\hline Education Group & Frequency & Prosentase \\
\hline No school & 0 & 0 \\
Basic & 3 & 18,75 \\
Intermediate & 13 & 81,25 \\
High & 0 & 0 \\
\hline Total & 16 & 100 \\
\hline
\end{tabular}

Based on table 2 it can be interpreted that almost all of the respondents $(81,25 \%)$ have intermediate education.

3) Distribution of Respondents by Occupation

Tabel 3 Frequency Distribution of Respondent Characteristics by Occupation at Jatikalen Public Helath Center Nganjuk District

\begin{tabular}{lcc}
\hline Pekerjaan & Frekuensi & Prosentase \\
\hline Housewife & 7 & 43,75 \\
Farmer & 2 & 12,5 \\
Private & 6 & 37,5 \\
Enterpreneur & 0 & 0 \\
Civil Servant & 1 & 6,25 \\
\hline Total & 16 & 100 \\
\hline
\end{tabular}

Based on table 3 it can be interpreted that almost half $(43,75 \%)$ of the respondents work as housewife.

\section{4) Distribution of Respondents by Labor Information}

Tabel 4 Frequency Distribution of Respondent Characteristics by Labor Information at Jatikalen Public Health Center Nganjuk District

\begin{tabular}{lcc}
\hline Labor Information & Frequency & Prosentase \\
\hline Magazines / Newspaper & 0 & 0 \\
Health Workers & 9 & 56,25 \\
Television/Radio & 1 & 6,25 \\
Friend/Brother & 2 & 12,5 \\
Has Never Been & 4 & 25 \\
\hline Total & 16 & 100
\end{tabular}

Based on table 4 it can be interpreted that most $(56,25 \%)$ respondents get information on childbirth from health workers. 


\section{STRADA Jurnal Ilmiah Kesehatan}

DOI: $10.30994 /$ sjik.v9i2.428

ISSN: 2252-3847 (print); 2614-350X (online)

Vol.9 No.2 November 2020 Page.1056-1064

\section{Special Data}

1) Distribution of Respondents Based on Anxiety Level in Primigravida Pregnant Women Before Giving Chocolate Consumption

Tabel 5 Frequency Distribution of Respondent Characteristics Based on The Anxiety Level of Primigravida Pregnant Women Befire Giving Chocolate Consumption at Jatikalen Public Health Center, Nganjuk District

\begin{tabular}{lcc}
\hline \multicolumn{1}{c}{ Anxiety Levels } & Frequency & Prosentase \\
\hline Not Anxious & 2 & 12,5 \\
Mild Anxiety & 2 & 12,5 \\
Moderate Anxiety & 12 & 75 \\
Heavy Anxiety & 0 & 0 \\
\hline Total & 16 & 100 \\
\hline
\end{tabular}

Based on table 5 it can be interpreted that most $(75 \%)$ of the respondents studied before being given chocolate consumption experienced moderate anxiety.

2) Distribution of Respondents Based on Anxiety Level in Primigravida Pregnant Women After Giving Chocolate Consumption

Tabel 6 Frequency Distribution of Respondent Characteristics Based on Anxiety Levels of Primigravida Pregnant Women After Giving Chocolate Consumption at Jatikalen Health Center, Nganjuk District

\begin{tabular}{lcc}
\hline \multicolumn{1}{c}{ Anxiety Levels } & Frequency & Prosentase \\
\hline Not Anxious & 11 & 68,75 \\
Mild Anxiety & 3 & 18,75 \\
Moderate Anxiety & 2 & 12,5 \\
Heavy Anxiety & 0 & 0 \\
\hline Total & 16 & 100 \\
\hline
\end{tabular}

Based on table 6 , it can be interpreted that most $(68,75 \%)$ of the respondents studied after being given chocolate consumption did not experience anxiety.

3) The Effect of Chocolate Consumption on Anxiety Levels in Primigravida Pregnant Women at Jatikalen Public Helath Center Nganjuk District

Tabel 7 Frequency Distribution of Respondent Characteristics Based on The Effect of Chocolate Consumption on Anxiety Levels of Primigravida Pregnant Women at Jatikalen Health Center, Nganjuk District

\begin{tabular}{|c|c|c|c|c|c|c|c|c|}
\hline \multirow{3}{*}{$\begin{array}{c}\text { Chocolate } \\
\text { Consumption }\end{array}$} & \multicolumn{6}{|c|}{ Anxiety Levels } & \multirow{2}{*}{\multicolumn{2}{|c|}{ Total }} \\
\hline & \multicolumn{2}{|c|}{ Not Anxious } & \multicolumn{2}{|c|}{ Mild } & \multicolumn{2}{|c|}{ Moderate } & & \\
\hline & $\mathrm{F}$ & $\%$ & $\mathrm{~F}$ & $\%$ & $\mathrm{~F}$ & $\%$ & $\mathrm{~F}$ & $\%$ \\
\hline Before & 2 & 12,5 & 2 & 12,5 & 12 & 75 & 16 & 100 \\
\hline After & 11 & 68,75 & 3 & 18,75 & 2 & 12,5 & 16 & 100 \\
\hline$p$ value $=0,00$ & & 0,05 & & & & & & \\
\hline
\end{tabular}

Based on table 7 above, the level of anxiety in primigravida pregnant women before giving chocolate consumption can be interpreted, namely that most (75\%) of the respondents experienced moderate anxiety and a small portion $(12.5 \%)$ of the respondents experienced mild anxiety and did not experience anxiety. While the 


\section{STRADA Jurnal Ilmiah Kesehatan}

DOI: $10.30994 /$ sjik.v9i2.428

ISSN: 2252-3847 (print); 2614-350X (online)

Vol.9 No.2 November 2020 Page.1056-1064

level of anxiety in primigravida pregnant women after giving chocolate consumption can be interpreted, namely that most $(68.75 \%)$ of the respondents experienced no anxiety and a small portion (18.75\%) experienced mild anxiety, and (12.5\%) experienced moderate anxiety.

Based on the results of statistical tests using the Wilcoxon signed-rank test, it is known that the $\mathrm{p}$-value of 0.001 is smaller than the value of $\alpha=0.05(0.002<0.05)$ so that $\mathrm{H} 0$ is rejected and $\mathrm{H} 1$ is accepted, meaning that there is an effect of giving chocolate consumption on the anxiety level of pregnant women. Primigravida at Jatikalen, Health Center Nganjuk District.

\section{DISCUSSION}

1) Anxiety Level in Primigravida Pregnant Women Before Giving Chocolate Consumption at Jatikalen Health Center Nganjuk District

Based on the results of the study showed that most $(75 \%)$ of the respondents who were studied before being given chocolate consumption experienced moderate anxiety, while a small proportion (12.5\%) experienced mild anxiety and did not experience anxiety. Anxiety is a physically fearful and unpleasant situation that warns a person of imminent danger. Pregnancy and childbirth are natural processes that a woman experiences. However, not every woman will always be ready for labor because labor is accompanied by pain and bleeding. Unpreparedness will cause fear and anxiety to the mother, especially in women who have given birth for the first time because in general, they do not have a description of the events that will be experienced at the end of pregnancy, especially at delivery (Glover 2014). Anxiety can cause tension in the pelvic floor muscles which play an important role in labor which increases pain (Ding et al. 2014). Excess pain increases fear, anxiety, and tension in the face of childbirth. Other studies have shown that anxiety can cause the release of the stress-inducing hormone cortisol into the general circulation. High cortisol levels lead to decreased uterine arterial blood flow leading to slow or even stopping uterine contractions (Glover 2014). A decrease in the efficiency of uterine contractions will increase the duration of labor. Long labor can increase complications for mother and baby (Cicek and Basar 2017). Other studies have shown that the bad effects of pregnant women's anxiety trigger the stimulation of uterine contractions. The result of this condition can increase blood pressure so that it can trigger preeclampsia and miscarriage (Pevi Primasnia, Wagiyo 2013). Low birth weight babies (LBW) and premature babies are also a negative impact of anxiety in pregnant women(Hasim et al. 2018).

In the process of giving birth to a baby, psychological effects can inhibit and slow down the birth process or it can also accelerate the birth of the baby, so the biological function of reproduction is strongly influenced by the psychological life and emotional life of the woman concerned (Martini et al. 2015). Based on studies related to the incidence of prolonged labor, $65 \%$ are due to inefficient uterine contractions. According to Old et al (2000), there is a dysfunctional uterine contraction in response to anxiety that inhibits uterine activity. This response is part of the psychological component, so it can be stated that psychological factors influence the disruption of the labor process. According to Priyoto (2014), pregnancy often brings a feeling of anxiety which will affect both the mother and the fetus physically and psychologically, for example resulting in physical disabilities and deterioration of the potential for intelligence and mental-emotional aspects (Priyoto 2014). 


\section{STRADA Jurnal Ilmiah Kesehatan}

DOI: $10.30994 /$ sjik.v9i2.428

ISSN: 2252-3847 (print); 2614-350X (online)

Vol.9 No.2 November 2020 Page.1056-1064

Unpreparedness will cause fear and anxiety to the mother, especially for women who have given birth for the first time because in general, they do not have a description of the events that will be experienced at the end of pregnancy, especially during childbirth. Anxiety will mobilize individual defenses. The way individuals defend themselves against anxiety can be seen from the symptoms that determine the type of disorder (Winda Martalisa 2013).

\section{2) Anxiety Level in Primigravida Pregnant Women After Giving Chocolate Consumption at Jatikalen Health Center Nganjuk District}

Based on the results of the study, it was found that most $(68.75 \%)$ of the respondents studied after being given chocolate consumption did not experience anxiety. And a small proportion (18.75\%) experienced mild anxiety and (12.5\%) experienced moderate anxiety. One of the non-pharmacological efforts to overcome anxiety in dealing with childbirth is consuming chocolate. Chocolate is the name for the processed food or drinks from cocoa beans (Theobroma cacao). Chocolate was first consumed by the inhabitants of ancient Mesoamerica as a drink. Fruit skin has 10 grooves 1-2 cm thick. Chocolate has also become one of the most popular flavors in the world, apart from the most commonly consumed chocolate bar, chocolate is also an ingredient in hot and cold drinks (Kristanto Aji 2012). Most of the substances contained in chocolate are theobromine which can stimulate the nerve and heart tissue which keeps the body awake and energized. Besides that, chocolate also contains phenylethylamine which functions to help the absorption of nutrients in the brain and produce dopamine which will cause feelings of joy, increase feelings of attraction, and can cause feelings of love. Chocolate with more than $70 \%$ cocoa (cocoa beans) content has health benefits because chocolate is rich in antioxidants, namely phenols and flavonoids. With the presence of antioxidants, chocolate can capture free radicals in the body. The amount of antioxidants is even 3 times more than green tea, a drink that has been considered an antioxidant. Chocolate also contains several vitamins that are good for body health, such as vitamin A, vitamin B1, vitamin C, vitamin D, and vitamin $\mathrm{E}$, besides chocolate also contains substances and nutrients that are important for the body such as iron, potassium, and calcium. Research conducted by researchers at the Nestle Research Center in Lausanne, Switzerland published in the Journal of Proteome Research shows that consuming this type of chocolate every day for two weeks can reduce levels of the stress hormone cortisol and catecholamines in those with high anxiety levels. Researchers looked at the effects of consuming 40 grams of dark chocolate daily for two weeks with urine and blood measurements in 30 healthy adults. Participants' levels of anxiety were determined at the start of the study, and samples for both blood and urine were collected and analyzed at the start and end of the two-week study. The result is that daily consumption of dark chocolate will reduce stress hormone levels in those with high anxiety levels (Jayantika 2012).

\section{3) The Effect of Chocolate of Anxiety Levels in Primigravida Pregnant Women at Jatikalen Health Center Nganjuk District}

The results of the research presented in cross-tabulation in table 7 show that out of a total of 16 respondents, most $(75 \%)$ of respondents experienced moderate anxiety and a small portion (12.5\%) of respondents experienced mild anxiety and did not experience anxiety before consuming chocolate. . While the level of anxiety in primigravida pregnant women after giving chocolate consumption, namely most $(68.75 \%)$ of the 


\section{STRADA Jurnal Ilmiah Kesehatan}

DOI: $10.30994 /$ sjik.v9i2.428

ISSN: 2252-3847 (print); 2614-350X (online)

Vol.9 No.2 November 2020 Page.1056-1064

respondents experienced no anxiety and a small proportion $(18.75 \%)$ experienced mild anxiety and $(12.5 \%)$ experienced moderate anxiety. Based on the results of statistical tests with the Wilcoxon signed-rank between before and after giving chocolate consumption to primigravida pregnant women, it is known that the p-value of 0.001 is smaller than the value of $\alpha=0.05(0.001<0.05)$ so that $\mathrm{H} 0$ is rejected and $\mathrm{H} 1$ is accepted, meaning that There is the Effect of Chocolate Consumption on Anxiety Levels of Primigravida Pregnant Women at Jatikalen Health Center, Nganjuk District.

Chocolate contains hundreds of substances that allow chemical reactions in the brain, these substances stimulate the active serotonin in the brain which will trigger a person's feeling of comfort. Besides, the most substance contained in chocolate is theobromine which can stimulate the nervous and heart tissue which keeps the body awake and energized. Chocolate also contains phenylethylamine which helps the absorption of nutrients in the brain and produces dopamine which will cause feelings of joy. As reported by Boldsky's page, in a study conducted by Harvard University, it was found that chocolate has a substance that can be a neurotransmitter to reduce depression. The cacao content in dark chocolate is believed to have anti-depressant properties that can increase the enzyme's serotonin, phenylethylamine, and dopamine. Other studies have shown that consuming chocolate every day for two weeks can reduce levels of the stress hormone cortisol and also catecholamines in those with high anxiety levels (Jayantika 2012). Even so, various controversies still color the real benefits of dark chocolate. On the one hand, no one denies its properties, especially after these properties are supported by various studies and scientific evidence. Therefore doctors do not recommend consuming this dark chocolate in large quantities (Jayantika 2012).

\section{CONCLUSION}

Based on the results of research conducted at Jatikalen Health Center, Nganjuk District, it can be concluded that there is an effect of giving chocolate consumption on the level of anxiety in primigravida pregnant women. Suggestions for the next researcher should the researcher continue the research by conducting the first trials of the research instrument so that its validity and reliability can be accepted so that the results can be representative. And it is hoped that further researchers can develop this research by examining other benefits of chocolate for the health of both pregnant women and the general public.

\section{REFERENCES}

Bann, Carla M et al. 2016. "Psychometric Properties of Stress and Anxiety Measures among Nulliparous Women." Journal of Psychosomatic Obstetrics 8 Gynecology 0(0): 1-11. http://dx.doi.org/10.1080/0167482X.2016.1252910.

Bunevičius, Adomas, Eglè Čèsnaitè, Laima Kusminskas, and Robertas Bunevičius. 2015. "Antenatal Maternal Mental State and Anthropometric Characteristics of the Neonates: I . Impact of Symptoms of Depression and Anxiety Antenatalinè Motinu Psichikos Būsena Ir Antropometrinès Naujagimių Charakteristikos : I . Depresijos Ir Nerimo Simptomų I.." Biologine Psichiatrija IR Psichofarmakologija 1(January 2007).

Cicek, Sevil, and Fatma Basar. 2017. "SC." Complementary Therapies in Clinical Practice: 1-21. https://doi.org/10.1016/j.ctcp.2017.10.006. 


\section{STRADA Jurnal Ilmiah Kesehatan}

DOI: $10.30994 /$ sjik.v9i2.428

ISSN: 2252-3847 (print); 2614-350X (online)

Vol.9 No.2 November 2020 Page.1056-1064

Darvill, Ruth, Heather Skirton, and Qualified Midwife. 2010. "Psychological Factors That Impact on Women' S Experiences of First-Time Motherhood: A Qualitative Study of the Transition." Midwifery 26(3): 357-66. http://dx.doi.org/10.1016/j.midw.2008.07.006.

Ding, Xiu-xiu et al. 2014. "Maternal Anxiety during Pregnancy and Adverse Birth Outcomes : A Systematic Review and Meta-Analysis of Prospective Cohort Studies." Journal of Affective Disorders 159(81): 103-10.

Dipietro, Janet, and Heather L Sipsma. 2008. "Journal of Psychosomatic Obstetrics." Journal of Psychosomatic Obstetric and Gycenologi (June).

Fauzia Laili, Endang Wartini. 2017. "One Group Pre- Post Test Design." Jurnal Kebidanan Malahayati 3(3): 152-56.

George, Astrid et al. 2013. "Anxiety Symptoms and Coping Strategies in the Perinatal Period." Anxiety symptoms and coping strategies in the perinatal period 13: 233.

Glover, Vivette. 2014. "Best Practice \& Research Clinical Obstetrics and Gynaecology Maternal Depression, Anxiety and Stress during Pregnancy and Child Outcome; What Needs to Be Done." Best Practice \& Research Clinical Obstetrics \& Gynaecology 28(1): 25-35. http://dx.doi.org/10.1016/j.bpobgyn.2013.08.017.

Goodman, Janice H, D Ph, Lynda Tyer-viola, and D Ph. 2010. "Detection , Treatment , and Referral of Perinatal Depression and Anxiety by Obstetrical Providers." Journal of Women's Health 19(3).

Hasim, Rizqika Pradewi et al. 2018. "Gambaran Kecemasan Ibu Hamil." Universitas Muhammadiyah Surakarta.

Jayantika, Erika. 2012. "Khasiat Cokelat Untuk Ibu Hamil. Kumpulan Artikel Wanita Hamil Dan Kehamilan."

Kristanto Aji. 2012. Bisnis Dan Manfaat Cokelat Untung Dan Sehat Semakin Mendekat. Yogyakarta: Penerbit Pustaka Baru Press.

Martini, Julia et al. 2015. "Risk Factors and Course Patterns of Anxiety and Depressive Disorders during Pregnancy and after Delivery: A Prospective-Longitudinal Study." Journal of Affective Disorders 175: 385-95.

Pevi Primasnia, Wagiyo, Elisa. 2013. "KECEMASAN IBU PRIMIGRAVIDA DALAM MENGHADAPI PROSES PERSALINAN KALA I DI RUMAH BERSALIN KOTA UNGARAN." Prosiding Konferensi Nasional PPNI Jawa Tengah: 212-16.

Priyoto. 2014. Konsep Manajemen Stres. Yogyakarta: Nuha Medika.

Schetter, Christine Dunkel, and Lynlee Tanner. 2012. "Anxiety, Depression and Stress in Pregnancy: Implications for Mothers , Children , Research , and Practice." Behavioural Medicine 25(2): 141-48.

Shapiro, Gabriel D, and William D Fraser. 2016. "Psychosocial Stress in Pregnancy and Preterm Birth : Associations and Mechanisms." J. Perinat Med.Author 41(6): 631-45.

Winda Martalisa, Wulan Budisetyani. 2013. "Hubungan Intensitas Keikutsertaan Hypnobirthing Dengan Tingkat Kecemasan Ibu Hamil Di Gianyar Winda Martalisa Dan Wulan Budisetyani.” Jurnal Psikologi Udayana 1(1): 116-28. 